\title{
MENINGKATKAN HASIL BELAJAR MATEMATIKA MATERI OPERASI HITUNG BILANGAN BULAT DENGAN PENGGUNAAN ALAT PERAGA PADA SISWA KELAS V SD NEGERI 1 BAADIA
}

\author{
Mariati Ado \\ Dinas Pendidikan, Pemuda, dan Olahraga Kota Baubau, SD Negeri 1 Baadia \\ E-mail:adomariati@yahoo.co.id
}

\begin{abstract}
Abstrak
Tujuan penelitian ini adalah untuk mengetahui efektivitas penggunaan alat peraga untuk meningkatkan hasil belajar matematika materi operasi hitung bilangan bulat pada siswa kelas V SD Negeri 1 Baadia. Penelitian ini dilaksanakan di SD Negeri 1 Baadia, Kota Baubau. Subjek dalam penelitian ini siswa kelas V SD Negeri 1 Baadia yang berjumlah 21 orang (12 siswa laki-laki dan 9 siswa perempuan). Penelitian ini merupakan penelitian tindakan kelas, dilakukan dalam dua siklus. Hasil penelitian menunjukan bahwa penanaman konsep pembelajaran matematika materi Operasi Hitung Bilangan Bulat melalui penggunaan alat peraga dapat memberikan kesempatan kepada siswa untuk terlibat secara langsung dalam proses pembelajaran dan dapat meningkatkan hasil belajar siswa.
\end{abstract}

Kata kunci: alat peraga, hasil belajar, Matematika.

\begin{abstract}
The purpose of this study was to determine the effectiveness of the use of props to improve mathematics learning outcomes matter integer arithmetic operations on class $V$ students of SD Negeri 1 Baadia. This research was conducted in SD Negeri 1 Baadia, City Baubau. Subjects in this study fifth grade students of SD Negeri 1 Baadia totaling 21 people (12 boys and 9 girls). This research is a classroom action research, conducted in two cycles. The results showed that planting material math learning concepts Operation Count Integer through the use of props can provide opportunities for students to become directly involved in the learning process and can improve student learning outcomes.
\end{abstract}

Keywords: props, learning outcomes, Math. 


\section{SANG PENCERAH}

Volume 2, Nomor 2, Agustus 2016, ISSN 2460-5697, Hlm. 29-38

Mariati Ado: Meningkatkan Hasil Belajar Matematika ...

\section{Pendahuluan}

Mata pelajaran matematika adalah mata pelajaran yang bersifat rasional, dapat dihitung, diukur dan diamati serta sangat erat peranannya dalam berbagai aktivitas kehidupan sehari-hari. Matematika merupakan mata pelajaran utama di Sekolah Dasar (SD). Namun kenyataannya, banyak problematika yang dikeluhkan oleh guru SD sehubungan dengan pelajaran matematika seperti rendahnya hasil belajar siswa baik pada saat tes formatif, tes MID semester, ulangan semester maupun pada saat ujian nasional. Pembelajaran merupakan suatu interaksi dan hubungan yang dilakukan secara sistematis tentang suatu konsep yang bertujuan untuk melatih, membantu, memotivasi dan menyenangkan peserta didik dalam belajarnya, sehingga dapat mencapai tujuan pembelajaran tertentu. Hal ini sesuai dengan pendapat (Sanjaya, 2005:17) yang menyatakan bahwa pembelajaran adalah proses interaksi baik antara manusia dengan mansuia ataupun antara manusia dengan lingkungan, sehingga akan tercapai tujuan yang telah ditetapkan.

Apabila masalah belajar dikaitkan dengan proses pembelajaran di sekolah, maka salah satu indikator yang dapat dijadikan pedoman untuk melihat dan mengukur perubahan pada anak didik melalui hasil belajarnya. Masalah keberhasilan peserta didik merupakan suatu hal penting yang perlu dilakukan oleh warga sekolah. Karena keberhasilan dalam belajar perlu didukung oleh faktor internal dan eksternal pada suatu lembaga pendidikan. Prestasi belajar adalah sebagai hasil yang dicapai oleh individu setelah suatu proses belajar dalam jangka waktu tertentu. Sehingga seseorang dapat mengetahui tingkat kemampuan dan kecakapan yang sudah dimilikinya (Hamalik, 2004:23). Belajar adalah suatu usaha sadar yang dilakukan oleh para pendidik kepada anak didik untuk merubah perilaku, menanamkan pengetahuan, sehingga terjadi perubahan positif pada diri seseorang, baik keterampilan, kebiasaan, pemahaman, tingkah laku, kecakapan, kemampuan yang dihasilkan dari pengalaman dan pelatihan. Adapun secara umum belajar dikatakan sebagai tahapan dari perubahan tingkah laku individu yang relatif sebagai hasil pengalaman dan dapat berinteraksi dengan lingkungannya serta melibatkan aspek kognitif, afektif dan psikomotorik. Slameto (2010:74) menyebutkan bahwa belajar adalah suatu proses usaha yang dilakukan seseorang untuk memperoleh suatu perubahan tingkah laku yang baru secara keseluruhan, sebagai hasil pengalamannya sendiri dalam interaksi dengan lingkungannya.

Hasil belajar adalah suatu kemampuan yang dimiliki peserta didik setelah menerima pengalaman belajarnya dan memperoleh pengetahuan yang lebih baik, keterampilan, kebiasaan, sikap, dan cita-cita dari kehidupan. Hasil belajar digunakan oleh guru untuk dijadikan kriteria dalam mencapai suatu tujuan pendidikan. Hal ini dapat tercapai apabila peserta didik sudah memahami belajar dan disertai dengan perubahan. Hasil belajar bermakna dari dua sisi yaitu peserta didik dan guru. Sisi peserta didik hasil belajar merupakan tingkat perkembangan mental yang lebih baik bila dibandingkan pada saat sebelum belajar. Tingkat perkembangan mental terwujud pada ranah kognitif, ranah afektif dan ranah psikomotor. Sedangkan sisi guru, hasil belajar merupakan suatu umpan balik dalam pelaksanaan proses belajar mengajar, baik bahan pelajaran, metode, model, pendekatan, media, evaluasi dan pengayaan pembelajaran. Hamalik (2006:118) menuliskan bahwa hasil belajar adalah apabila seseorang telah belajar akan terjadi perubahan tingkah laku pada orang tersebut, misalnya dari tidak tahu menjadi tahu dan dari tidak mengerti menjadi mengerti. 


\section{SANG PENCERAH}

Volume 2, Nomor 2, Agustus 2016, ISSN 2460-5697, Hlm. 29-38

Mariati Ado: Meningkatkan Hasil Belajar Matematika ...

Pembelajaran matematika volume bangun ruang di kelas $\mathrm{V}$ pada dasarnya merupakan mata pelajaran yang berkesinambungan. Namun pembelajaran tentang operasi hitung bilangan bulat dalam pemecahan masalah belum menunjukkan hasil sesuai dengan harapan. Hal ini dapat diketahui dari hasil belajar siswa pada saat ulangan harian dari 21 siswa kelas V SD Negeri 1 Baadia banyak yang nilainya masih berada di bawah KKM. Rendahnya hasil belajar siswa dikarenakan minimnya pemahaman konsep terhadap materi pelajaran. Sebagai seorang figur yang bijaksana, guru dituntut untuk menepis anggapan bahwa matematika merupakan suatu mata pelajaran yang sangat rumit, sukar dan manakutkan. Hal ini dapat terlaksana bila dalam proses pembelajaran guru menggunakan model dan strategi pembelajaran yang tepat (Hamalik, 2006:47). Selain itu, untuk meningkatkan keaktifan siswa guru dapat menggunakan alat peraga untuk menciptakan suasana pembelajaran yang menyenangkan karena siswa dilibatkan secara langsung dan materi lebih mudah dipelajari (Rahardi, 2003 :9).

Dalam proses pembelajaran, kedudukan media pembelajaran berupa alat peraga mempunyai multi fungsi, salah satunya adalah mempermudah penalaran siswa pada materi pelajaran yang bersifat abstrak ke bentuk konkrit (Achmads, 1996:11). Pemanfaatan alat peraga (berupa kertas bergaris bilangan positif dan negatif) dalam pembelajaran matematika pada materi Operasi Hitung Bilangan Bulat sangat membantu mempermudah siswa memahami konsep menentukan letak dan nilai bilangan. Karena siswa mampu mengembangkan kreativitasnya dengan mengukur panjang masing-masing bilangan dari titik koordinat untuk menentukan nilai suatu bilangan. Oleh karena itu dalam pembelajaran matematika khususnya pada materi operasi hitung bilangan bulat dalam pemecahan masalah, pemanfaatan alat peraga kertas bilangan bulat dengan melibatkan siswa secara aktif dalam proses pembelajaran sehingga dapat membantu penyampaian materi dan penanaman konsep. Berdasarkan uraian di atas, Fokus penelitian ini adalah bagaimana meningkatkan hasil belajar matematika materi operasi hitung bilangan bulat dengan menggunakan alat peraga pada siswa kelas V SD Negeri 1 Baadia?

Tujuan penelitian ini adalah untuk mengetahui efektivitas penggunaan alat peraga untuk meningkatkan hasil belajar matematika materi operasi hitung bilangan bulat pada siswa kelas V SD Negeri 1 Baadia.

\section{Metode Penelitian}

Penelitian ini dilaksanakan di SD Negeri 1 Baadia, Kecamatan Murhum Kota Baubau Sulawesi Tenggara. Subjek dalam penelitian ini siswa kelas V SD Negeri 1 Baadia yang berjumlah 21 orang (12 siswa laki-laki dan 9 siswa perempuan). Penelitian ini merupakan penelitian tindakan kelas, dilakukan dalam dua siklus. Adapun langkahlangkah yang digunakan untuk setiap siklus meliputi, perencanaan, tindakan, observasi, dan refleksi. Sumber data berupa data primer (nilai tes formatif pada kondisi awal, nilai tes setelah pelaksanaan siklus I \& nilai tes setelah pelaksanaan siklus II) dan sumber data sekunder berasal dari catatan-catatan dan temuan selama pelaksanaan penelitian tahap siklus I dan tahap siklus II.

Data yang terkumpul kemudian dianalisis dengan menggunakan analisis diskriptif komparatif (membandingkan nilai pada kondisi awal dengan nilai hasil siklus I dan siklus II) dan analisis deskripsi kualitatif didasarkan pada 


\section{SANG PENCERAH}

Volume 2, Nomor 2, Agustus 2016, ISSN 2460-5697, Hlm. 29-38

Mariati Ado: Meningkatkan Hasil Belajar Matematika ...

hasil observasi dan refleksi dari tiap-tiap siklus. Indikator keberhasilan didasarkan pada perbandingan antara hasil belajar kondisi awal dengan hasil belajar Siklus I dan hasil belajar Siklus II. Indikator keberhasilan tersebut adalah hasil pengolahan data dalam bentuk tabel perbandingan hasil belajar dan diagram.

\section{Pembahasan}

\section{Deskripsi Kondisi Awal}

Pada kondisi awal, sebelum pelaksanaan perbaikan pembelajaran dari 21 siswa didapat data nilai sebagai berikut (1) 5 siswa pada rentang nilai antara 40 - 49; (2) 6 siswa pada rentang nilai antara 50 - 59; (3) 4 siswa pada rentang nilai antara 60 - 69; (4) 3 siswa pada rentang nilai antara 70 - 69; dan (5) 3 siswa pada rentang nilai antara $80-89$. Jumlah nilai sebesar 1130, rerata sebesar 54, Kriteri Ketuntasan Minimal (KKM) sebesar 65, nilai tertinggi adalah 80, Nilai terendah adalah 40 , jumlah tuntas sebanyak 6 siswa, dan jumlah belum tuntas sebanyak 15 siswa dengan presentase ketuntasan $28 \%$.

KKM pada mata pelajaran Matematika kelas $\mathrm{V}$ yang ditentukan oleh SD Negeri 1 Baadia adalah 65. Berdasarkan nilai ketuntasan pada saat kondisi awal sebelum perbaikan pembelajaran hanya dicapai oleh 6 siswa atau $28 \%$, dari sejumlah 21 siswa, dengan nilai rata-rata kelas hanya mencapai 65. Rendahnya hasil belajar pada kondisi awal tersebut mengidikasikan bahwa tujuan pembelajaran tidak tercapai. Oleh karena itu perlu dilaksanakan perbaikan pembelajaran. Tujuan dari perbaikan pembelajaran ini adalah agar jumlah siswa dapat mencapai nilai tuntas klasikal (75\%).

\section{Deskripsi Hasil Penelitian Siklus I}

\section{a. Rencana}

Dalam rangka perbaikan pembelajaran di kelas $\mathrm{V}$ tentang melakukan operasi hitung bilangan bulat dalam pemecahan masalah melalui penggunaan media pembelajaran bagi siswa kelas V SD Negeri 1 Baadia peneliti menyusun rencana perbaikan pembelajaran yang meliputi tujuan perbaikan pembelajaran, materi pembelajaran, sarana penunjang, rencana perbaikan pembelajaran Siklus I. Pada Rencana perbaikan dalam siklus I ini menekankan pada penggunaan alat peraga.

\section{b. Tindakan}

Pelaksanaan

perbaikan pembelajaran tentang penjumlahan bilangan bulat postif dan negatif melalui penggunaan alat peraga pada Siklus I dapat meningkatkan hasil belajar siswa. Hal ini dibuktikan dengan rata-rata siswa mampu mengerjakan lembar kerja serta mampu mengerjakan soal tes formatif di akhir pelajaran. Selanjutnya untuk mengetahui tingkat keberhasilan pelaksakaan Siklus I, perlu adanya perbandingan hasil belajar pada kondisi awal dan sesudah pelaksaan perbaikan pembelajaran pada siklus I yaitu sebagai berikut (1) 0 siswa pada rentang nilai antara 40 - 49; 0 siswa pada rentang nilai antara 50 - 59; 9 siswa pada rentang nilai antara 60 69; 8 siswa pada rentang nilai antara 70 - 69; 4 siswa pada rentang nilai 
Mariati Ado: Meningkatkan Hasil Belajar Matematika ...

antara 80 - 89; jumlah nilai sebesar 1420; rerata sebesar 67; KKM pada sikulus I diperoleh 68; nilai tertinggi adalah 80; nilai terendah adalah 60 ; jumlah tuntas sebanyak 12; jumlah belum tuntas 9 dengan presentase ketuntasan 57\%. Data di atas selanjutnya dianalisis secara deskriptif komparatif, yaitu membandingkan hasil belajar pada kondisi awal dengan hasil belajar setelah pelaksanaan siklus I.

Tabel 1 Hasil Belajar Sebelum dan Sesudah Perbaikan Siklus I

\begin{tabular}{ccc}
\hline \multirow{2}{*}{ Rentang Nilai } & \multicolumn{2}{c}{ Banyak Siswa } \\
\cline { 2 - 3 } & $\begin{array}{c}\text { Sebelum } \\
\text { Perbaikan }\end{array}$ & $\begin{array}{c}\text { Perbaikan } \\
\text { Siklus I }\end{array}$ \\
\hline $50-49$ & 5 siswa & 0 siswa \\
$60-69$ & 6 siswa & 0 siswa \\
$70-79$ & 4 siswa & 9 siswa \\
$80-89$ & 3 siswa & 8 siswa \\
$90-99$ & 3 siswa & 4 siswa \\
100 & 0 siswa & 0 siswa \\
Jumlah Siswa & 0 siswa & 0 siswa \\
Jumlah Nilai & $\mathbf{2 1}$ & $\mathbf{2 1}$ \\
KKM & $\mathbf{1 1 3 0}$ & $\mathbf{1 4 2 0}$ \\
Nilai Tertinggi & $\mathbf{6 5}$ & $\mathbf{6 8}$ \\
Nilai Terendah & $\mathbf{8 0}$ & $\mathbf{8 0}$ \\
Jumlah Tuntas & $\mathbf{4 0}$ & $\mathbf{6 0}$ \\
Belum Tuntas & $\mathbf{6}$ & $\mathbf{1 2}$ \\
Persentase Tuntas & $\mathbf{1 5}$ & $\mathbf{9}$ \\
\hline
\end{tabular}

Perbandingan hasil belajar di atas dapat disajikan dalam bentuk diagram berikut.

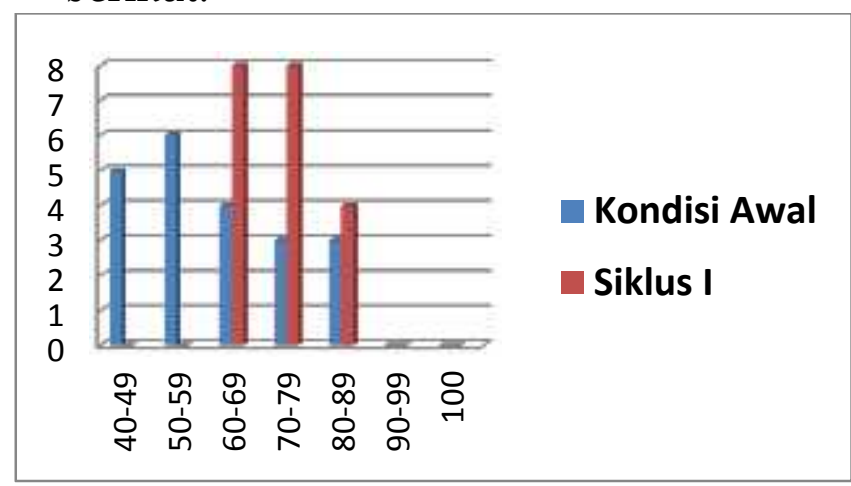

Gambar 1 Hasil Belajar Kondisi Awal dan Siklus I

\section{c. Pengamatan}

Hasil pengamatan teman sejawat pada pelaksanaan Siklus I adalah sebagai berikut.

\section{Guru}

a) Guru telah melaksanakan kegiatan persiapan pembelajaran melalui penyusunan RPP dan kelengkapannya yang disusun secara sistematis.

b) Pelaksanaan kegiatan pembelajaran sesuai dengan RPP dengan menggunakan metode dan strategi pembelajaran. Namun demikian penyajian materi belum dilaksanakan secara urut.

c) Pelaksanaan pembelajaran juga menggunakan alat peraga belum maksimal

d) Pemantauan guru terhadap pelaksanaan kerja kelompok belum maksimal sehingga masih ada siswa yang kurang aktif tetapi luput dari perbahatian guru.

e) Bimbingan oleh guru masih bersifat umum dan belum mengarah pada masing-masing kelompok yang mengalami kesulitan

f) Kegiatan pembelajaran diakhiri dengan pelaksanaan tes formatif

2. Siswa

a) Beberapa siswa pada saat kerja kelompok masih terlihat pasif

b) Ketrampilan siswa mengerjakan lembar tugas telah cukup baik

c) Aktivitas siswa pada saat diskusi kelas masih didominasi oleh beberapa siswa saja. 
Mariati Ado: Meningkatkan Hasil Belajar Matematika ...

d) Peningkatan hasil belajar siswa belum sesuai dengan tujuan perbaikan pembelajaran.

\section{d. Refleksi}

Setelah perbaikan pembelajaran siklus I dilaksanakan, peneliti berdiskusi dengan teman sejawat untuk mengetahui keberhasilan dan kekurangan siklus I. Adapun keberhasilan yang diperoleh berdasarkan pengamatan dan analisis data hasil tes formatif, diketahui bahwa terdapat perbaikan pembelajaran melakukan operasi hitung bilangan bulat dalam pemecahan masalah melalui pemanfaatn alat peraga bagi siswa kelas V SD Negeri 1 Baadia, walaupun telah terjadi peningkatan namun belum mencapai target jumlah ketuntasan klasikal 75\%.

Kekurangan pada siklus I, sesuai dengan hasil pengamatan teman sejawat adalah teknik pembimbingan guru terhadap siswa masih bersifat klasikal, beberapa siswa masih bersifat pasif, jumlah siswa yang belum mencapai tuntas masih cukup tinggi. Hal ini dapat terjadi karena guru belum menerapkan bimbingan secara kelompok maupun individu. Hasil diskusi tersebut menjadi bahan kajian dan pembahasan sebagai bahan pertimbangan pelaksanaan perbaikan pada tahap berikutnya yaitu pada Siklus II.

\section{Deskripsi Hasil Penelitian Siklus II} a. Rencana

Di dalam rangka
masalah perbaikan
pembelajaran pada Siklus II disusun

berdasar kekurangan pada siklus I yang meliputi tujuan perbaikan pembelajaran, materi pembelajaran, metode dan strategi yang akan dilaksanakan, sarana penunjang. Rencana perbaikan pembelajaran Siklus II yang peneliti susun sebagai upaya untuk meningkatkan hasil belajar tentang melakukan operasi hitung bilangan bulat dalam pemecahan masalah melalui penggunaan alat peraga.

\section{b. Tindakan}

Pada Pelaksanaan Perbaikan pembelajaran Siklus II, diketahui bahwa hasil belajar siswa mengalami kemajuan yang sangat baik. Dari data yang terkumpul dapat dilihat perbandingan peningkatan hasil belajar siswa mengalami peningkatan yang cukup signifikan. Hasil perbaikan pembalajaran pada siklus II secara lengkap adalah sebagai berikut 0 siswa pada rentang nilai antara 40 49; 0 siswa pada rentang nilai antara 50 - 59; 0 siswa pada rentang nilai antara 60 - 69; 0 siswa pada rentang nilai antara 70 - 69; 9 siswa pada rentang nilai antara 80 - 89; 6 siswa pada rentang nilai antara 90 - 99; 6 siswa pada nilai 100; jumlah nilai sebesar 1690; rerata sebesar 80; KKM pada siklus II diperoleh 68; nilai tertinggi adalah 100; nilai terendah adalah 80; jumlah tuntas 21 siswa; pada siklus ini tidak terdapat lagi siswa tidak tuntas, pelaksanaan siklus ini presentase ketuntasan mencapai $100 \%$.

Hasil belajar pada siklus II dapat meningkat ditandai dengan ketuntasan tingkat klasikal seluruh 


\section{SANG PENCERAH}

Volume 2, Nomor 2, Agustus 2016, ISSN 2460-5697, Hlm. 29-38

Mariati Ado: Meningkatkan Hasil Belajar Matematika ...

siswa (dari 21 siswa) 100\% dengan nilai rata-rata kelas 80 . Peningkatan hasil belajar yang sangat signifikan ini telah melampaui target perbaikan pembelajaran yang semula hanya direncanakan 75\%. Peningkatan hasil belajar pada siklus II dapat disajikan dalam Tabel 2 dan Gambar 2.

Tabel 2 Hasil Belajar Sebelum dan Sesudah Perbaikan Siklus I dan Siklus II

\begin{tabular}{cccc}
\hline \multirow{2}{*}{ Rentang Nilai } & \multicolumn{3}{c}{ Banyak Siswa } \\
\cline { 2 - 4 } & $\begin{array}{c}\text { Sebelum } \\
\text { Perbaikan }\end{array}$ & $\begin{array}{c}\text { Perbaikan } \\
\text { Siklus I }\end{array}$ & $\begin{array}{c}\text { Perbaikan } \\
\text { Siklus I }\end{array}$ \\
\hline $40-49$ & 5 siswa & 0 siswa & 0 siswa \\
$50-59$ & 6 siswa & 0 siswa & 0 siswa \\
$60-69$ & 4 siswa & 9 siswa & 0 siswa \\
$70-79$ & 3 siswa & 8 siswa & 0 siswa \\
$80-89$ & 3 siswa & 4 siswa & 9 siswa \\
$90-99$ & 0 siswa & 0 siswa & 6 siswa \\
100 & 0 siswa & 0 siswa & 6 siswa \\
\hline Jumlah Siswa & $\mathbf{2 1}$ & $\mathbf{2 1}$ & $\mathbf{2 1}$ \\
Jumlah Nilai & $\mathbf{1 1 3 0}$ & $\mathbf{1 4 2 0}$ & $\mathbf{1 6 9 0}$ \\
Rata - rata & $\mathbf{5 4}$ & $\mathbf{6 8}$ & $\mathbf{8 0}$ \\
KKM & $\mathbf{6 5}$ & $\mathbf{6 8}$ & $\mathbf{6 8}$ \\
Nilai Tertinggi & $\mathbf{8 0}$ & $\mathbf{8 0}$ & $\mathbf{1 0 0}$ \\
Nilai Terendah & $\mathbf{4 0}$ & $\mathbf{6 0}$ & $\mathbf{8 0}$ \\
Jumlah Tuntas & $\mathbf{6}$ & $\mathbf{1 2}$ & $\mathbf{2 1}$ \\
Belum Tuntas & $\mathbf{1 5}$ & $\mathbf{9}$ & $\mathbf{0}$ \\
Persentase Tuntas & $\mathbf{2 8} \%$ & $\mathbf{5 7 \%}$ & $\mathbf{1 0 0 \%}$ \\
\hline
\end{tabular}

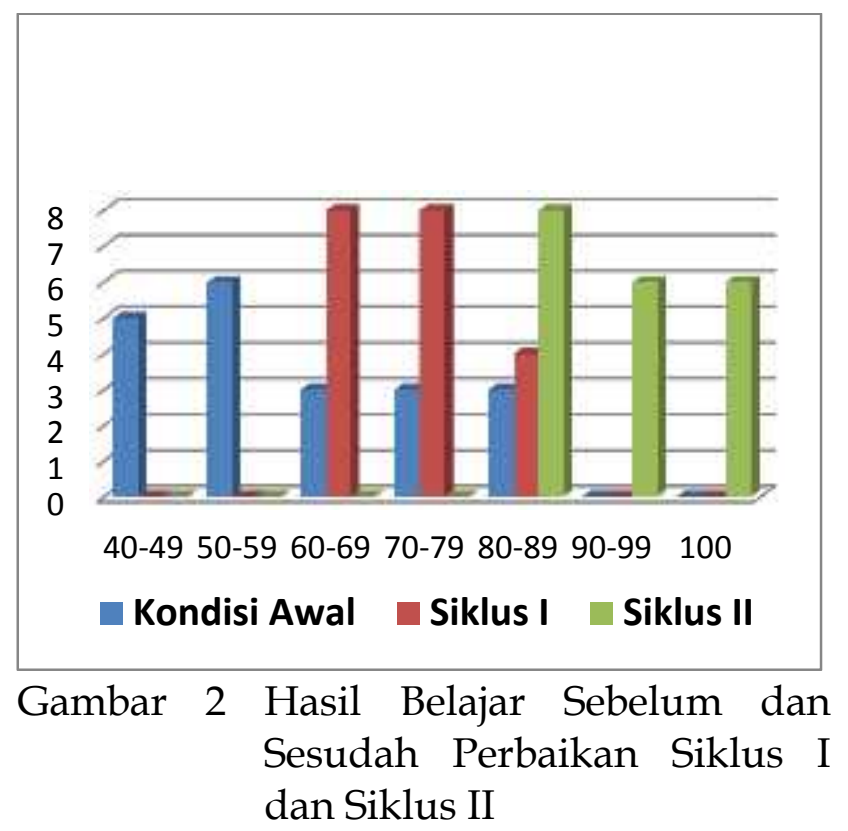

Adapun perbandingan persentase hasil belajar sebelum perbaikan dan setelah perbaikan siklus I dan siklus II dapat dilihat pada Gambar 3 berikut:

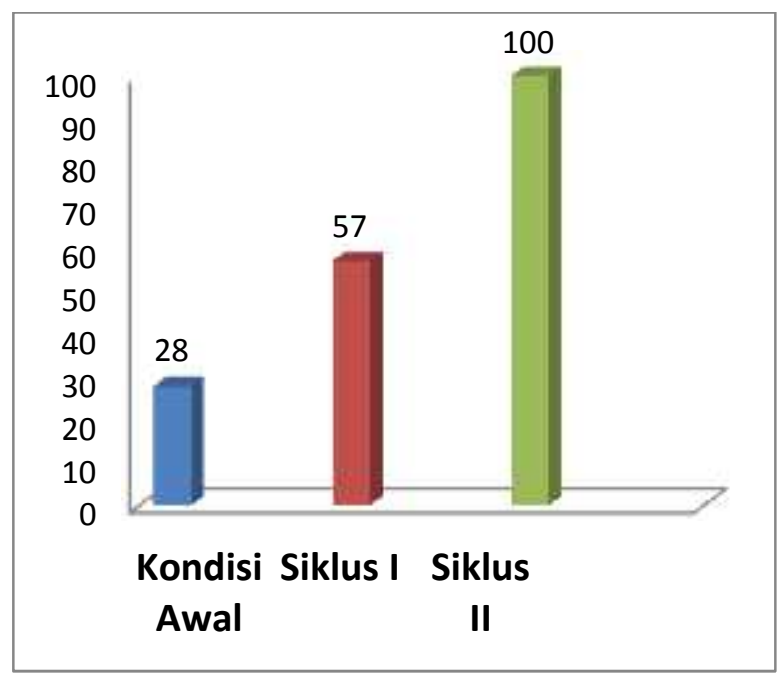

Gambar 3 Persentase Hasil Belajar Sebelum dan Sesudah Perbaikan Siklus I dan Siklus II

\section{c. Pengamatan}

Hasil pengamatan teman sejawat pada pelaksanaan Siklus II adalah sebagai berikut.

1. Guru

a) Guru telah melaksanakan kegiatan persiapan pembelajaran melalui penyusunan RPP dan kelengkapannya yang disusun secara sistematis.

b) Pelaksanaan kegiatan pembelajaran sesuai dengan RPP dengan menggunakan metode dan strategi pembelajaran dengan penyajian materi disampaikan secara urut.

c) Pelaksanaan pembelajaran juga menggunakan alat peraga

d) Pemantauan Guru terhadap pelaksanaan kerja kelompok 


\section{SANG PENCERAH}

Volume 2, Nomor 2, Agustus 2016, ISSN 2460-5697, Hlm. 29-38

Mariati Ado: Meningkatkan Hasil Belajar Matematika ...

secara maksimal sehingga siswa termotivasi untuk aktif

e) Bimbingan oleh guru telah ditekankan pada masing-masing kelompok yang mengalami kesulitan.

f) Kegiatan pembelajaran diakhiri dengan pelaksanaan tes formatif

\section{Siswa}
a) Beberapa siswa pada saat kerja kelompok terlihat semakin aktif
b) Ketrampilan siswa mengerjakan
lembar tugas semakin meningkat
c) Aktivitas siswa pada saat diskusi kelas masih menggambarkan suasana kelas yang hidup.
d) Peningkatan hasil belajar siswa telah sesuai dengan tujuan perbaikan pembelajaran
e) Hasil belajar meningkat sangat signifikan
f) Siswa menyenangi mata pelajaran matematika

\section{d. Refleksi}

Hasil pengamatan teman sejawat dapat disimpulkan adalah bahwa secara umum pelaksanaan perbaikan pembelajaran pada siklus II dapat dinyatakan berhasil dan sesuai dengan tujuan perbaikan pembelajaran.

Sebelum perbaikan pembelajaran dilaksanakan, umumnya siswa kurang memahami materi pelajaran yang disampaikan guru. Hal ini disebabkan adanya beberapa faktor yang mempengaruhi tidak tercapainya tujuan pembelajaran seperti minat belajar siswa terhadap mata pelajaran matematika masih rendah, umumnya siswa kurang memahami konsep materi pelajaran penjumlahan bilangan bulat positif dan negatif yang disampaikan guru, pembelajaran kurang bermakna karena guru hanya terpancang menerapkan satu metode saja, yaitu metode ceramah, dalam penyampaikan materi pelajaran, guru tidak menggunakan alat peraga untuk mempermudah penelaahan materi yang bersifat abstrak ke bentuk konkritdan proses pembelajaran terkesan monoton karena guru tidak mengaktifkan siswa dan tidak memberikan kesempatan siswa untuk bertanya.

Pada pelaksanaan perbaikan pembelajaran siklus I Guru hanya menggunakan teori hakekat pembelajaran sehingga komunikasi antara guru dengan siswa belum terjalin secara akrab. Dari hasil pelaksanaan siklus I sebagaimana disajikan dalam diagram batang, dari 21 siswa hanya 57\% yang mencapai nilai tuntas tingkat klasikal. Oleh karena itu perbaikan pembelajaran siklus I dinyatakan belum sesuai dengan tujuan perbaikan atau dinyatakan belum berhasil walaupun hasil belajar siswa cukup mengalami peningkatan. Belum berhasilnya pelaksanaan siklus I disebabkan karena teknik pembimbingan guru terhadap siswa masih bersifat klasikal, beberapa siswa masih bersifat pasif. Hal ini dapat terjadi akibat guru belum menerapkan bimbingan secara kelompok maupaun secara individu serta belum menggunakan alat peraga. Selanjutnya pelaksanaan dan hasil siklus I dijadikan bahan kajian untuk perbaikan pembelajaran pada tahap berikutnya yaitu siklus II. 


\section{SANG PENCERAH}

Volume 2, Nomor 2, Agustus 2016, ISSN 2460-5697, Hlm. 29-38

Mariati Ado: Meningkatkan Hasil Belajar Matematika ...

Pada siklus II, peneliti lebih menekankan pada pendekatan pembelajaran yang menekankan pada ranah kognitif, afektif dan psikomotorik. Ranah kognitif tersebut dijadikan landasan untuk menanamkan pengetahuan dan konsep pembelajaran kepada siswa. Hal ini dimaksudkan untuk meningkatkan hasil belajar siswa, dengan memotivasi siswa untuk rajin belajar dan berlatih. Pendekatan strategi pembelajaran dengan tiga ranah tersebut dalam pelaksanan perbaikan pembelajaran siklus II adalah merupakan hasil pengkajian dari penggunaan teori tabularasa yang diterapkan pada pelaksanaan siklus I yang belum memberikan hasil secara maksimal.

Penerapan alat peraga pada perbaikan pembelajaran siklus II mampu memotivasi belajar siswa sehingga hasil belajar meningkat dan tujuan perbaikan pembelajaran mencapai hasil yang menggembirakan, yaitu dengan naiknya ketuntasan klasikal sebesar $100 \%$ atau sejumlah 21 siswa telah berhasil tuntas. Peningkatan hasil belajar yang sangat signifikan tersebut disebabkan karena guru telah melaksanakan bimbingan baik secara individu maupun kelompok. Dimana dalam proses pembelajaran, siswa aktif memanfaatkan alat peraga yang disediakan guru untuk setiap kelompok. Dari pengamatan teman sejawat yang selalu mendampingi selama perbaikan pembelajaran siklus II diketahui adanya temuan-temuan yang bersifat mendukung peningkatan hasil belajar meliputi siswa terlibat secara aktif dalam proses pembelajaran, siswa lebih bersemangat dalam mengerjakan lembar tugas dalam hal pemecahan masalah melalui kerja kelompok, pembelajaran yang menggunakan media (alat peraga) dapat melibatkan siswa secara aktif dengan mengubah materi pelajaran yang bersifat abstrak ke bentuk konkrit. Karena anak mengalami secara langsung melalui pengamatan (menggunakan alat peraga dan pemecahan masalah), dampaknya memberikan kesan bahwa mata pelajaran matematika adalah mata pelajaran yang menyenangkan.

\section{Simpulan}

Simpulan penelitian ini bahwa penanaman konsep pembelajaran matematika materi Operasi Hitung Bilangan Bulat melalui penggunaan alat peraga dapat memberikan kesempatan kepada siswa untuk terlibat secara langsung dalam proses pembelajaran dan dapat meningkatkan hasil belajar siswa.

\section{Daftar Pustaka}

Achmad. 1996. Pengelolaan Kegiatan Belajar Mengajar Sekolah Dasar. Jakarta: Depdikbud.

Hamalik. 2004. Kurikulum dan Pembelajaran. Jakarta: Bumi Aksara. 2006. Strategi Pembelajaran Terpadu. Bandung: Karya Setia.

Muchtar. 2003. Matematika $V$ B. Jakarta: Yudhistira.

Rahardi. 2003. Media Pembelajaran. Jakarta: Depdikbud. 


\section{SANG PENCERAH}

Volume 2, Nomor 2, Agustus 2016, ISSN 2460-5697, Hlm. 29-38

Mariati Ado: Meningkatkan Hasil Belajar Matematika ...

Sanjaya, W. 2005. Pembelajaran dalam Implementasi Kurikulum Berbasis Kompetensi. Jakarta: Kencana Prenada Media Group.

Slameto. 2010. Teori-Teori Belajar. Jakarta: Intan Pariwara.

Suprayekti. 2003. Interaksi Belajar Mengajar. Jakarta: Depdiknas. 